ScIDice

\section{Assessment Of Furcation Defects In Diabetic Patients With Chronic Periodontitis - An Institutional Based Retrospective Study \\ Research Article}

Reshma Thirunavakarasu ${ }^{1}$, Balaji Ganesh $\mathrm{S}^{*}$

${ }^{1}$ Saveetha Dental College and Hospitals, Saveetha Institute of Medical and Technical Sciences, Saveetha University, Chennai, India.

${ }^{2}$ Senior Lecturer, Department of Periodontology, Saveetha Dental College and Hospitals, Saveetha Institute of Medical and Technical Sciences, Saveetha University, Chennai, India.

\title{
Abstract
}

Diabetes Mellitus (DM) is a metabolic disorder characterized by chronic hyperglycemia and disturbances of carbohydrate, fat and protein metabolism. Poorly controlled DM has been associated with increased susceptibility to oral infections including periodontal diseases. It is well documented that one of the main causes of diabetes mellitus is that it leads to periodontal destruction which eventually leads to furcation exposure. This leads to poor prognosis of the affected tooth. Thus the aim of this study is to determine the most common furcation site involved in patients with diabetes. Completed case sheets were collected from June 2019 to April 2020. Data was retrieved and evaluated by 2 reviewers. This university setting study involved 700 sample sizes. Data is tabulated the parameters which are age groups, gender, RBS value and furcation grade. Ranges of RBS values are from $150 \mathrm{mg} / \mathrm{dl}$ to $>551 \mathrm{mg} / \mathrm{dl}$. A total of 700 patients case sheets were evaluated and their periodontal status was evaluated. 500 molars were affected (3rd molars exempted). It was found that among all the age groups the most number of participants were seen in 41-60 years (66\%). Majority of the affected molars has a grade II furcation involvement $(45 \%)$. $35.40 \%$ had grade I furcation involvement followed by $15.60 \%$ of affected teeth with grade III furcation involvement and finally $4 \%$ had grade IV furcation involvement. Amongst the teeth with grade I and grade III it was found that 16 was the mostly affected. For grade II furcation involvement it was seen that 46 was mostly affected. Association between grade I, II and III furcation and age groups was statistically insignificant. Finally, 37 was the most affected among the teeth with grade IV furcation involvement. Association between grade IV furcation and age groups was statistically significant $(p$ value $=0.006)$ Thus we can conclude that diabetes mellitus is associated with periodontal disease and in this study it is evident that it involves the furcation area of molars. Diabetic patients are more prone to severe periodontitis with multiple furcation involvement.

Keywords: Chronic Periodontitis; Diabetes Mellitus; Furcation; Innovation.

\section{Introduction}

Diabetes Mellitus (DM) is a metabolic disorder characterized by chronic hyperglycemia and disturbances of carbohydrate, fat and protein metabolism $[2,33]$, Type I DM is most common in children and adolescents whereas Type II DM affects adults. Type II DM constitutes about $90-95 \%$ of all patients having the disease [30]. Both types I and II have a genetic predisposition, the aetiology of type II is related to lifestyle factors such as fat and sugar intakes, physical inactivity and obesity [30] Worldwide; 346 million people suffer from DM [38]. Periodontitis is a chronic inflam- matory condition which is initiated by gram negative organisms, which affects the tooth supporting structures [28, 34, 48, 49, 44]. It can also be said as an interaction between pathogenic bacteria and the immune and inflammatory response of host [21, 22]. Periodontitis is characterized by persistent inflammation, which causes loss of periodontal tissues $[9,39,58]$. It leads to destruction of periodontal tissues namely the gingiva, periodontal ligament, cementum and alveolar bone $[4,52,47]$.

The association between periodontal diseases and diabetes mellitus (DM) is well documented [12]. There has found to be a link between DM, tooth loss and periodontal prognosis. There are

\section{*Corresponding Author:}

Balaij Ganesh S,

Senior Lecturer, Department of Periodontology, Saveetha Dental College, Saveetha Institute of Medical and Technical Sciences (SIMATS), Saveetha University, Chennai - 600 077, Tamil Nadu, Chennai.

Tel: 8220713554

Email ID: balajiganeshs.sdc@saveetha.com

Received: February 25, 2021

Accepted: March 04, 2021

Published: March 09, 2021

Citation: Reshma Thirunavakarasu, Balaji Ganesh S. Assessment Of Furcation Defects In Diabetic Patients With Chronic Periodontitis - An Institutional Based Retrospective Study. Int J Dentistry Oral Sci. 2021;08(03):1977-1983. doi: http://dx.doi.org/10.19070/2377-8075-21000390

Copyright: Balaji Ganesh S ${ }^{\top} 2021$. This is an open-access article distributed under the terms of the Creative Commons Attribution License, which permits unrestricted use, distribution and reproduction in any medium, provided the original author and source are credited. 
various prognostic factors, local site-related factors such as probing depth (PD), mobility and furcation involvement which may be controlled by periodontal therapy however there are certain patient level factors such as smoking, plaque control and DM control. Poorly controlled DM has been associated with increased susceptibility to oral infections including periodontal diseases [33]. Loe [29] stated that periodontal disease is the sixth most common complication of DM whereas Lalla et al., [23] reported that DM is the strongest risk factor for periodontal infection compared to the other systemic condition such as hypertension. Periodontal therapy aids in eliminating the disease and maintaining the function, healthy dentition and supporting tissues $[55,50]$ Due to a rise in periodontal disease which are left untreated, it leads to an increase in loss of teeth. Thus various replacements methods are available such as dental implants [51, 19].

Furcation involvement is when there is an exposure of interradicular areas to the periodontal pocket in bifurcated or trifurcated roots [16, 14]. Furcation involvement can be due to many reasons which are inflammation caused by microorganisms in the subgingival biofilm, predisposing factors such as enamel projections into the furcation; proximity of the furcation to the cemento-enamel junction; accessory canals extending the pulp inflammation to the furcation and the presence of interradicular canals on the floor of the pulp cavity and finally modifying factors which are trauma from occlusion which leads to greater bone loss [10, 16, 54] Furcation involvement often affects the molar teeth but less frequently involves the upper premolars [24]. Nabers probe is the instrument of choice when clinically examining the interradicular region. Radiographic examination is also an aid in determining the furcation involvement. Improved radiographic techniques will indicate the existence or absence of bone loss although it only provides a two dimensional image of the upper and lower jaw. There are some cases in which surgical intervention is required to further appreciate the extension of bone destruction in the interradicular region in addition to clinical and radiographic examination [14]. Based on the literature, we can deduce that diabetes mellitus has an influence on the furcation involvement of molars. Our department is passionate about research we have published numerous high quality articles in this domain over the past years $[20,43,7,45,59,25,26,6,40,11,46,13,36,42,53,25,35,41$, $17,1,8,31,37,61,60,57,3,35]$. Thus the aim of the study is to assess the various types of furcation involvement in chronic periodontitis patients with diabetes mellitus.

\section{Materials and Methods}

This is a retrospective study regarding common furcation sites in diabetic patients who have visited Saveetha Dental College and Hospitals , from a given period of time which is June 2019 to April 2020. The approval for this university setting was obtained from the Institution of Ethics Board. Institutional ethical committee approval was obtained for the study (SDC/SIHEC/2020/ DIASDATA/0619-0320).Among patients who have visited the dental facility, the records of the patients were obtained from a given time period of June 2019 to April 2020. The sample size for this study was 700 patients. Inclusion criteria for this study were diabetes mellitus patients, gender (male/female), age above 17 years, presence of localised or generalised chronic periodontitis. Exclusion criteria were patients with smoking or other adverse habits, pregnancy and history of periodontal therapy done 6 months prior. All available data was collected and sorted. The patients detailed case sheets were analysed using the parameters included are: name, age, gender, random blood sugar values (RBS value), furcation grade (Grade I, Grade II, Grade III, and Grade IV). Age groups were grouped into (17-40 years, 41-60 years and $>61$ years). RBS values were grouped into $(150-250 \mathrm{mg} / \mathrm{dl}, 251$ $350 \mathrm{mg} / \mathrm{dl}, 351-450 \mathrm{mg} / \mathrm{dl}, 451-550 \mathrm{mg} / \mathrm{dl}$ and $>551 \mathrm{mg} / \mathrm{dl})$.

\section{Statistical Analysis}

Once the results have been tabulated based on the parameters, the data is then exported to SPSS software. Frequency and percentage were employed in the analysis. Chi square test was used to detect the significance between the age, gender, RBS value and furcation grade. $P$ value less than 0.05 was considered to be statistically significant.

\section{Results And Discussion}

A total of 700 patients with diabetes mellitus with RBS ranges of 150 to $>551 \mathrm{mg} / \mathrm{dl}$ participated in this study. It was found that the majority of the patients were males $(66.2 \%)$ whereas the remaining were females $(33.8 \%)$ which is depicted in Figure 1. Ages of patients were divided into three age groups which are 17-40 years, $40-61$ years and $>61$ years, it was found that among all the age groups the most number of participants were seen in 41-60 years $(66 \%)$ [Figure 2] Based on all 700 patients, it was found that 500 molars were affected. First and second molars in the upper and

Figure 1. Bar graph shows the number of patients based on gender. It was found that majority of the patients were males $(66.2 \%)$ whereas the remaining were females $(33.8 \%)$.

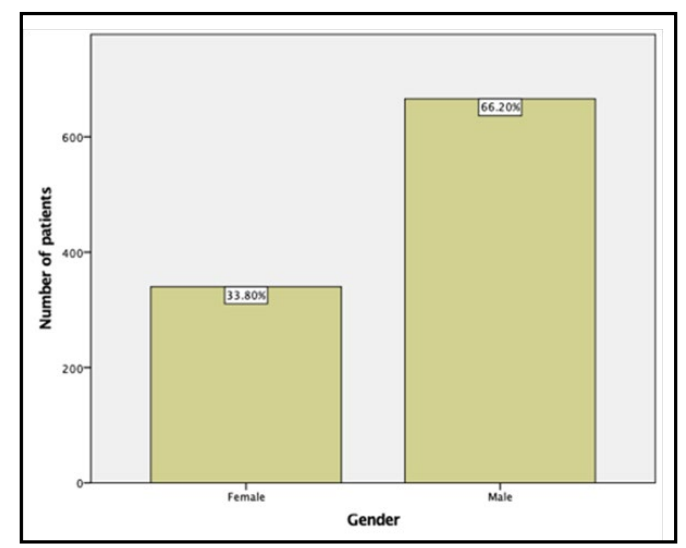


lower jaw were included in this study. Third molars were exempted from this study. Figure 3 shows that among all the affected molars, $45 \%$ of the molars had grade II furcation involvement. $35.40 \%$ had grade I furcation involvement followed by $15.60 \%$ of affected teeth with grade III furcation involvement and finally $4 \%$ had grade IV furcation involvement. Association between age group and RBS value was depicted in figure 4 . Highest number of patients with $150-250 \mathrm{mg} / \mathrm{dl}$ was seen in the $41-60$ years age group with $33.10 \%$. Patients with RBS of $>551 \mathrm{mg} / \mathrm{dl}$ were only seen in 17-40 years $(0.10 \%)$. This was found to be statistically significant $(\mathrm{p}$ value $=0.003)$. Association between gender and RBS value was also determined and depicted in figure 5. Majority of males $(35.09 \%$ ) have an RBS range of $150-250 \mathrm{mg} / \mathrm{dl}$. Similarly in females, $20.97 \%$ have an RBS value of $150-250 \mathrm{mg} / \mathrm{dl} .>551 \mathrm{mg} /$ $\mathrm{dl}$, was only seen in males with $0.10 \%$. This association was found to be statistically significant ( $\mathrm{p}$ value $=0.008$ ).

Association between age groups and grades of furcation was depicted from figure 6 to 9 . As we know the age group that has the most affected molars are patients in the 41-60 years age group. Firstly, association between the teeth grade I furcation defect and age group was depicted in Figure 6.16 was the most affected teeth $(11.30 \%)$ among patients in the 41-60 years age group. Among patients in the 17-40 years age group, 36 and 37 were the most

Figure 2. Bar graph shows the distribution of patients based on age groups. Highest number of patients was seen in 41-60 years $(66 \%)$ followed by $>61$ years with $20.68 \%$ and finally $17-40$ years with $13.32 \%$.

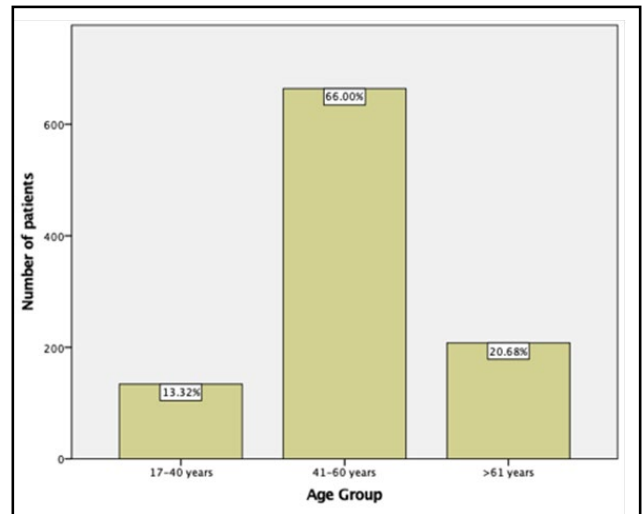

Figure 3. Bar graph shows the frequency of the number of affected molars with furcation involvement. $45 \%$ of the affected molars have a Grade II furcation involvement, $35.40 \%$ of the affected molars have a Grade I furcation involvement, $15.60 \%$

have a Grade III furcation involvement and the least is Grade IV furcation involvement with $4 \%$ of affected molars.

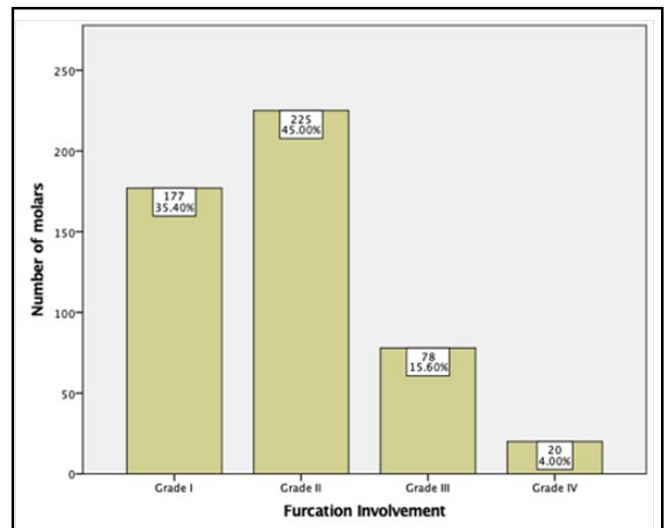

Figure 4. Bar graph shows the association between age groups and RBS values. $\mathrm{X}$ axis represents the age groups and $\mathrm{Y}$ axis represents the number of patients with diabetes. $150-250 \mathrm{mg} / \mathrm{dl}$ (blue) was found to be more in all three age groups compared to $251-350 \mathrm{mg} / \mathrm{dl}$ (green), $351-450 \mathrm{mg} / \mathrm{dl}$ (orange) $451-550$ (purple) and $>551 \mathrm{mg} / \mathrm{dl}$ (black). Highest number of patients with $150-250 \mathrm{mg} / \mathrm{dl}$ was seen in the $41-60$ years age group with $33.10 \%$. Patients with RBS of $>551 \mathrm{mg} / \mathrm{dl} \mathrm{were}$ only seen in $17-40$ years $(0.10 \%)$. Chi square test, $p$ value $=0.003(<0.05)$, hence statistically significant.

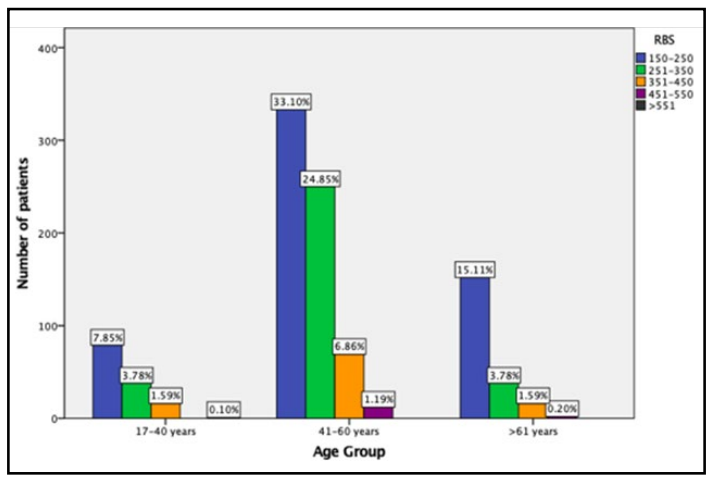


affected teeth $(2.82 \%)$ and it was found that 27 was not affected in this age group. Finally in patients $>61$ years of age, 16 was mostly affected with $3.95 \%$. This was found to be statistically insignificant ( $p$ value- 0.638 ). Figure 7 shows the association between teeth with grade II furcation defects and age groups. 46 was the most affected teeth in patients in the 41-60 years age group $(11.56 \%)$. Patients in the $17-40$ years age group, 27 , were mostly affected (3.56\%). 26 was the mostly affected teeth among patients $>61$ years of age with $2.22 \%$. P value was found to be statistically insignificant ( $p$ value-0.830). Next, the association is between teeth with grade III furcation defects and age groups [Figure 8]
16 was the most affected teeth in patients in the $41-60$ years age group $(16.67 \%)$. Patients in the $17-40$ years age group, 47 , were mostly affected (3.85\%). 26 was the mostly affected teeth among patients $>61$ years of age with $5.13 \%$. This association was found to be statistically insignificant $(\mathrm{p}$ value $=0.827$ ) Finally, Figure 9 shows the association between teeth with grade IV furcation defects and age groups. 37 was the most affected teeth in patients in the 41-60 years age group (25\%). Patients in the $17-40$ years age group, only 26 and 27 were affected with $5 \%$ each. 16 and 47 were the only affected teeth among patients $>61$ years with 16 being the mostly affected (15\%). P value was found to be statistically

Figure 5. Bar graph shows the association between gender and RBS values. $\mathrm{X}$ axis represents the gender and $\mathrm{Y}$ axis represents the number of patients with diabetes. $150-250 \mathrm{mg} / \mathrm{dl}$ (blue) was found to be the highest in males and females compared to $251-350 \mathrm{mg} / \mathrm{dl}$ (green), 351-450mg/dl (orange) $451-550$ (purple) and $>551 \mathrm{mg} / \mathrm{dl}$ (black). Majority of males (35.09\%) have an RBS range of $150-250 \mathrm{mg} / \mathrm{dl}$. Similarly in females, $20.97 \%$ have an $\mathrm{RBS}$ value of $150-250 \mathrm{mg} / \mathrm{dl}$. $>551 \mathrm{mg} / \mathrm{dl}$, was only seen in males with $0.10 \%$. Chi square test, $\mathrm{p}$ value $=0.008(<0.05)$, hence statistically significant.

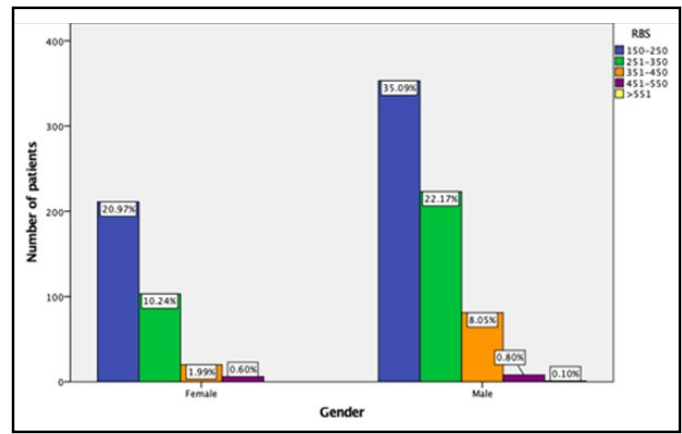

Figure 6. Bar graph shows the association between the teeth with grade $\mathrm{I}$ furcation defects and age groups. $\mathrm{X}$ axis represents the teeth with grade $I$ furcation involvement and $Y$ axis represents the number of molars affected. Patients in the 41-60 years age group (light blue) had more number of grade I furcations when compared to other age groups. 16 was the most affected teeth (11.30\%) among patients in the 41-60 years age group. Among patients in the 17-40 years age group, 36 and 37 were the most affected teeth $(2.82 \%)$ and it was found that 27 was not affected in this age group. Finally in patients $>61$ years of age, 16 was mostly affected with $3.95 \%$. Chi square test, $p$ value $=0.638(>0.05)$, hence statistically not significant.

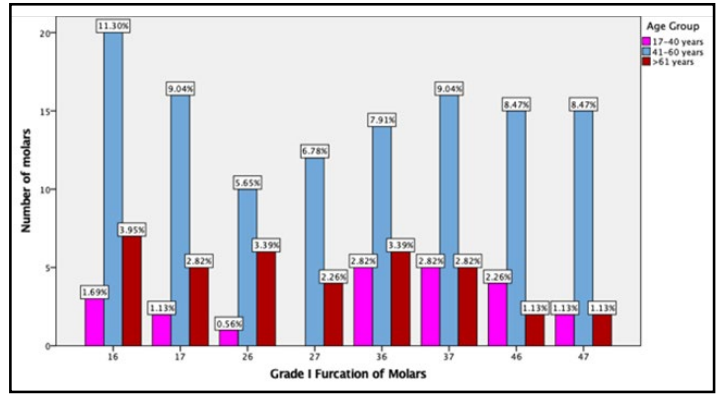

Figure 7. Bar graph shows the association between the teeth with grade II furcation defects and age groups. $\mathrm{X}$ axis represents the teeth with grade II furcation involvement and Y axis represents the number of molars affected. Patients in the 41-60 years age group (light blue) had more number of affected teeth compared to other age groups. 46 was the most affected teeth in patients in the $41-60$ years age group $(11.56 \%)$. Patients in the 17-40 years age group, 27, were mostly affected $(3.56 \%)$. 26 was the mostly affected teeth among patients $>61$ years of age with $2.22 \%$. Chi square test, $p$ value $=0.830$ $(>0.05)$, hence statistically not significant.

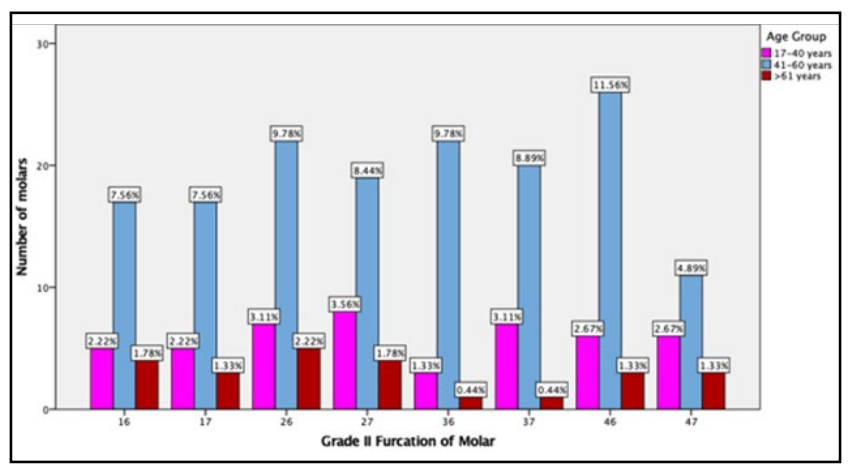


Figure 8. Bar graph shows the association between the teeth with grade III furcation defects and age groups. $\mathrm{X}$ axis represents the teeth with grade III furcation involvement and $\mathrm{Y}$ axis represents the number of molars affected. Patients in the 41-60 years age group (light blue) had more number of affected teeth compared to other age groups. 16 was the most affected teeth in patients in the 41-60 years age group (16.67\%). Patients in the 17-40 years age group, 47, were mostly affected $(3.85 \%)$. 26 was the mostly affected teeth among patients $>61$ years of age with $5.13 \%$. Chi square test, $p$ value $=0.827$ $(>0.05)$, hence statistically not significant

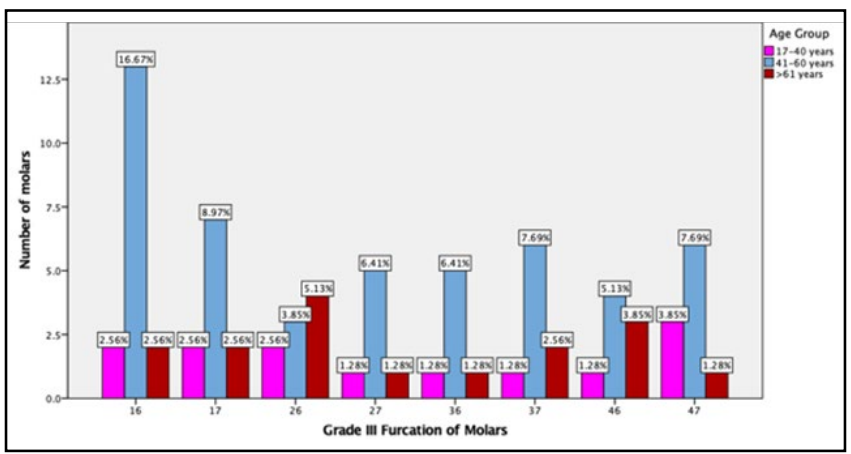

Figure 9. Bar graph shows the association between the teeth with grade IV furcation defects and age groups. $\mathrm{X}$ axis represents the teeth with grade IV furcation involvement and $\mathrm{Y}$ axis represents the number of molars affected. Patients in the 4160 years age group (light blue) had more number of affected teeth compared to other age groups. 37 was the most affected teeth in patients in the 41-60 years age group (25\%). Patients in the 17-40 years age group, only 26 and 27 were affected with $5 \%$ each. 16 and 47 were the only affected teeth among patients $>61$ years with 16 being the mostly affected (15\%). Chi square test, $\mathrm{p}$ value $=0.006(<0.05)$, hence statistically significant.

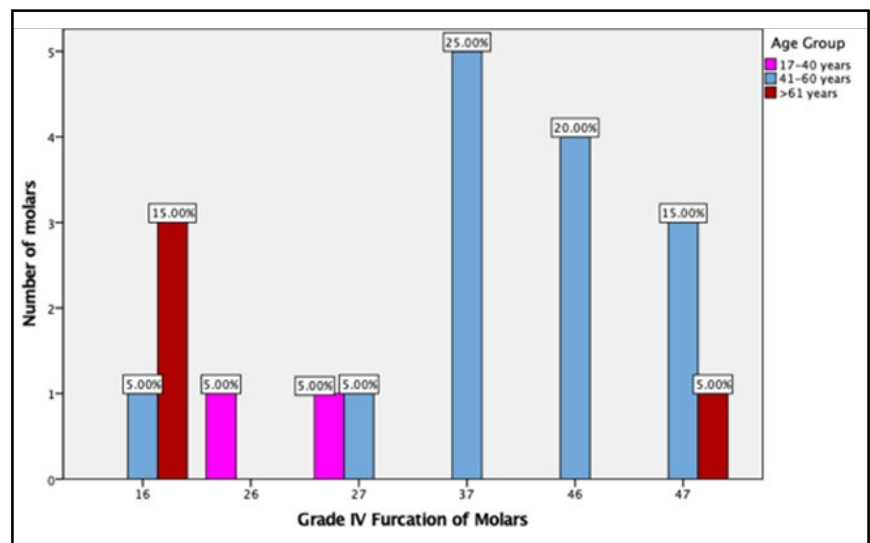

significant $(\mathrm{p}$ value$=0.006)$.

Based on our study, there was a male predilection in the number of patients with type II diabetes. However there is a study that suggests that diabetes (type II) is more frequently at risk seen in females due to the increased cases of obesity in females [18] There was a female predilection in patients with T2DM and chronic periodontitis in a study by Gusmao et al (14). Mohamed et al (33) also had a female predilection in among their participants with type II diabetes. In our study, the association between gender and RBS value were found to be statistically significant with a higher male predilection. $(\mathrm{p}<0.05)$. The participants with the highest number of affected molars belong to 41-60 years of age. About $66 \%$ of diabetic patients are $41-60$ years of age and they have the highest number of affected molars. Gopalakrishnan et al, had found that patients above 40 years of age were the majority of their participants $(n=22)$ and had the most number of affected teeth (176 teeth). However he suggested that the hazard rate was 2.5 times lower in the age group of above 40 years as compared to those below 40 years [12]. In our study, the association between age groups and RBS values were found to be statistically significant $(p<0.05)$. This proves that patients above 40 years of age are more prone to diabetes when compared to patients below 40 years. However patients of younger age are at greater risk for loss of molars if they do not control their blood sugar levels. Furcation involvement is mainly seen in the upper posteriors and lower posteriors. As discussed, diabetes has an effect on the periodontal status of a patient and leads to bone destruction, leading to exposed furcation of molars. In our study among the $700 \mathrm{pa}-$ tients, 500 molars were affected. Only first and second molars in the upper and lower jaw were included in this study. Third molars were exempted from this study. Among the 500 affected molars, $45 \%$ of the teeth have a grade II furcation involvement. A study showed that mandibular molars had a higher risk for loss than maxillary molars [12] A study which found similar results are from Miller et al [32] who found that there is a higher risk in maxillary molars. In a study (Mohamed et al., 2013), it was found that out of 447 patients, $23 \%$ of the participants had furcation involvement. Most of the patients in this study were poorly controlled. There are patients who were unaware of the diabetic status and are not under medications. There is a similar study which agrees with this statement. In that study [33] majority $(70 \%)$ of the T2DM patients were poorly controlled. This statement agrees with the data of other studies and illustrates the difficulties in maintaining good glycaemic control [15]. It has also stated that other studies reported that a significant worse periodontal condition among poorly controlled DM patients compared to patients with good metabolic control $[56,5,27]$. 
This study assesses the extent of furcation defects among patients with diabetes. Comparison between the ages groups of patients with diabetes and was done. Among all the furcation grading, patients in the 41-60 years age group have the most number of affected teeth. Amongst the teeth with grade I and grade III it was found that 16 was the mostly affected. For grade II furcation involvement it was seen that 46 was mostly affected. Finally, 37 was the most affected among the teeth with grade IV furcation involvement. Gusmao et al found that a total of $45.7 \%$ of the molars had furcation involvement whereas the remaining $54.3 \%$ had no furcation involvement despite the diagnosis of chronic periodontitis. In this same study they have found that a large portion of their cases $(56.9 \%)$ exhibited degree II and III furcation involvement. Thus, the importance of periodontal intervention of these affected molars is needed before further periodontal destruction takes place and thereby preventing tooth loss [14].

This study is unique as there are no previous studies which have determined the association between furcation involvement in patients with diabetes mellitus. Limitations of this study is that it is done among patients from a given period of time and does not represent a larger scale of diabetic patients.

\section{Conclusion}

Overall, 41-60 year old diabetic patients were mostly affected with chronic periodontitis which lead to furcation involvement. This study showed that, grade I and grade III furcation involvement was mostly seen in 16, grade II furcation involvement was seen mostly in 46 and finally, 37 was the most affected with grade IV furcation involvement. Thus this study proves that diabetic patients are more prone to severe periodontitis with multiple furcation involvement. Importance of oral health intervention should be emphasized among diabetic patients with chronic periodontitis.

\section{Acknowledgement}

The authors are thankful to Saveetha Dental College for providing a platform to express our knowledge.

\section{References}

[1]. Abdul Wahab PU, Senthil Nathan P, Madhulaxmi M, Muthusekhar MR, Loong SC, Abhinav RP. Risk Factors for Post-operative Infection Following Single Piece Osteotomy. J Maxillofac Oral Surg. 2017 Sep; 16(3): 328-332. PMID: 28717291.

[2]. Alberti KG, Zimmet PZ. Definition, diagnosis and classification of diabetes mellitus and its complications. Part 1: diagnosis and classification of diabetes mellitus provisional report of a WHO consultation. Diabet Med. 1998 Jul; 15(7): 539-53. PMID: 9686693.

[3]. Ashok BS, Ajith TA, Sivanesan S. Hypoxia-inducible factors as neuroprotective agent in Alzheimer's disease. Clin Exp Pharmacol Physiol. 2017 Mar; 44(3): 327-334. PMID: 28004401

[4]. Avinash K, Malaippan S, Dooraiswamy JN. Methods of Isolation and Characterization of Stem Cells from Different Regions of Oral Cavity Using Markers: A Systematic Review. Int J Stem Cells. 2017 May 30; 10(1): 12-20. PMID: 28531913.

[5]. Campus G, Salem A, Uzzau S, Baldoni E, Tonolo G. Diabetes and periodontal disease: a case-control study. J Periodontol. 2005 Mar; 76(3): 418-25. PMID: 15857077.

[6]. Danda AK. Comparison of a single noncompression miniplate versus 2 noncompression miniplates in the treatment of mandibular angle fractures: a prospective, randomized clinical trial. J Oral Maxillofac Surg. 2010 Jul;
68(7): 1565-7. PMID: 20430504.

[7]. Devi VS, Gnanavel BK. Properties of concrete manufactured using steel slag. Procedia Engineering. 2014 Jan 1; 97: 95-104.

[8]. Eapen BV, Baig MF, Avinash S. An Assessment of the Incidence of Prolonged Postoperative Bleeding After Dental Extraction Among Patients on Uninterrupted Low Dose Aspirin Therapy and to Evaluate the Need to Stop Such Medication Prior to Dental Extractions. J Maxillofac Oral Surg. 2017 Mar; 16(1): 48-52. PMID: 28286384.

[9]. Froum SJ, Gomez C, Breault MR. Current concepts of periodontal regeneration. A review of the literature. N Y State Dent J. 2002 Nov; 68(9): 14-22. PMID: 12442729.

[10]. Goldberg F, Massone EJ, Soares I, Bittencourt AZ. Accessory orifices: anatomical relationship between the pulp chamber floor and the furcation. J Endod. 1987 Apr; 13(4): 176-81. PMID: 3471840.

[11]. Gopalakannan S, Senthilvelan T, Ranganathan S. Modeling and optimization of EDM process parameters on machining of Al 7075-B4C MMC using RSM. Procedia Engineering. 2012 Jan 1; 38: 685-90.

[12]. Gopalakrishnan D, Miller PD, Mahuli AV, Sangamithra S, Phantumvanit P, Buranawat B. Evaluation of periodontally diseased molars in diabetics with Miller-McEntire Periodontal Prognostic Index. J Indian Soc Periodontol. 2018 Sep-Oct; 22(5): 401-405. PMID: 30210188.

[13]. Govindaraju L, Neelakantan P, Gutmann JL. Effect of root canal irrigating solutions on the compressive strength of tricalcium silicate cements. Clin Oral Investig. 2017 Mar; 21(2): 567-571. PMID: 27469101.

[14]. Gusmão ES, Picarte AC, Ben Barbosa MB, Rösing CK, Cimoes R. Correlation between clinical and radiographic findings on the occurrence of furcation involvement in patients with periodontitis. Indian J Dent Res. 2014 Sep-Oct; 25(5): 572-5. PMID: 25511053.

[15]. Hodge PJ, Robertson D, Paterson K, Smith GL, Creanor S, Sherriff A. Periodontitis in non-smoking type 1 diabetic adults: a cross-sectional study. J Clin Periodontol. 2012 Jan; 39(1): 20-9. PMID: 22092931.

[16]. Hou GL, Tsai CC. Relationship between periodontal furcation involvement and molar cervical enamel projections. J Periodontol. 1987 Oct; 58(10): 715-21. PMID: 3478466.

[17]. Jeevanandan G, Govindaraju L. Clinical comparison of Kedo-S paediatric rotary files vs manual instrumentation for root canal preparation in primary molars: a double blinded randomised clinical trial. Eur Arch Paediatr Dent. 2018 Aug; 19(4): 273-278. PMID: 30003514.

[18]. Kautzky-Willer A, Harreiter J, Pacini G. Sex and Gender Differences in Risk, Pathophysiology and Complications of Type 2 Diabetes Mellitus. Endocr Rev. 2016 Jun; 37(3): 278-316. PMID: 27159875.

[19]. Kavarthapu A, Thamaraiselvan M. Assessing the variation in course and position of inferior alveolar nerve among south Indian population: A cone beam computed tomographic study. Indian J Dent Res. 2018 Jul-Aug; 29(4): 405 409. PMID: 30127186.

[20]. Kavitha M, Subramanian R, Narayanan R, Udhayabanu V. Solution combustion synthesis and characterization of strontium substituted hydroxyapatite nanocrystals. Powder technology. 2014 Feb 1; 253: 129-37.

[21]. Khalid W, Vargheese SS, Lakshmanan R, Sankari M, Jayakumar ND. Role of endothelin-1 in periodontal diseases: A structured review. Indian J Dent Res. 2016 May-Jun; 27(3): 323-33. PMID: 27411664.

[22]. Khalid W, Varghese SS, Sankari M, Jayakumar ND. Comparison of Serum Levels of Endothelin-1 in Chronic Periodontitis Patients Before and After Treatment. J Clin Diagn Res. 2017 Apr; 11(4): ZC78-ZC81. PMID: 28571268.

[23]. Lalla E, Lamster IB. Assessment and management of patients with diabetes mellitus in the dental office. Dent Clin North Am. 2012 Oct; 56(4): 819-29. PMID: 23017553

[24]. Larato DC. Furcation involvements: incidence and distribution. J Periodontol. 1970 Sep; 41(9): 499-501. PMID: 5271937.

[25]. Lekha L, Raja KK, Rajagopal G, Easwaramoorthy D. Schiff base complexes of rare earth metal ions: Synthesis, characterization and catalytic activity for the oxidation of aniline and substituted anilines. Journal of Organometallic Chemistry. 2014 Mar 1; 753: 72-80.

[26]. Lekha L, Raja KK, Rajagopal G, Easwaramoorthy D. Synthesis, spectroscopic characterization and antibacterial studies of lanthanide (III) Schiff base complexes containing N, O donor atoms. Journal of Molecular Structure. 2014 Jan 6; 1056: 307-13.

[27]. Lim LP, Tay FB, Sum CF, Thai AC. Relationship between markers of metabolic control and inflammation on severity of periodontal disease in patients with diabetes mellitus. J Clin Periodontol. 2007 Feb; 34(2): 118-23. PMID: 17309586.

[28]. Löe H. The role of bacteria in periodontal diseases. Bull World Health Organ. 1981; 59(6): 821-5. PMID: 6978191.

[29]. Löe H. Periodontal disease. The sixth complication of diabetes mellitus. Diabetes Care. 1993 Jan; 16(1): 329-34. PMID: 8422804.

[30]. Mealey BL, Oates TW. American Academy of Periodontology. Diabetes mel- 
litus and periodontal diseases. J Periodontol. 2006 Aug; 77(8): 1289-303. PMID: 16881798.

[31]. Menon S. Selenium nanoparticles: A potent chemotherapeutic agent and an elucidation of its mechanism. Colloids Surf B Biointerfaces. 2018 Oct 1; 170: 280-292. PMID: 29936381

[32]. Miller PD Jr, McEntire ML, Marlow NM, Gellin RG. An evidenced-based scoring index to determine the periodontal prognosis on molars. J Periodontol. 2014 Feb; 85(2): 214-25. PMID: 23725028

[33]. Mohamed HG, Idris SB, Ahmed MF, Bøe OE, Mustafa K, Ibrahim SO, et al. Association between oral health status and type 2 diabetes mellitus among Sudanese adults: a matched case-control study. PLoS One. 2013 Dec 11; 8(12): e82158. PMID: 24349205.

[34]. Mootha A, Malaiappan S, Jayakumar ND, Varghese SS, Toby Thomas J. The effect of periodontitis on expression of interleukin-21: a systematic review. International journal of inflammation. 2016 Feb 22; 2016.

[35]. Neelakantan P, Cheng CQ, Mohanraj R, Sriraman P, Subbarao C, Sharma S. Antibiofilm activity of three irrigation protocols activated by ultrasonic, diode laser or Er:YAG laser in vitro. Int Endod J. 2015 Jun; 48(6): 602-10. PMID: 25080240.

[36]. Neelakantan P, Sharma S, Shemesh H, Wesselink PR. Influence of Irrigation Sequence on the Adhesion of Root Canal Sealers to Dentin: A Fourier Transform Infrared Spectroscopy and Push-out Bond Strength Analysis. J Endod. 2015 Jul; 41(7): 1108-11. PMID: 26008114.

[37]. Neelakantan P, Grotra D, Sharma S. Retreatability of 2 mineral trioxide aggregate-based root canal sealers: a cone-beam computed tomography analysis. J Endod. 2013 Jul; 39(7): 893-6. PMID: 23791258.

[38]. Organization WH. 'Fact sheets: diabetes'. 2013.

[39]. Panda S, Jayakumar ND, Sankari M, Varghese SS, Kumar DS. Platelet rich fibrin and xenograft in treatment of intrabony defect. Contemp Clin Dent. 2014 Oct; 5(4): 550-4. PMID: 25395778

[40]. Parthasarathy M, Isaac JoshuaRamesh Lalvani J, Dhinesh B, Annamalai K. Effect of hydrogen on ethanol-biodiesel blend on performance and emission characteristics of a direct injection diesel engine. Ecotoxicol Environ Saf. 2016 Dec; 134(Pt 2): 433-439. PMID: 26687456.

[41]. Patil SB, Durairaj D, Suresh Kumar G, Karthikeyan D, Pradeep D. Comparison of Extended Nasolabial Flap Versus Buccal Fat Pad Graft in the Surgical Management of Oral Submucous Fibrosis: A Prospective Pilot Study. J Maxillofac Oral Surg. 2017 Sep; 16(3): 312-321. PMID: 28717289.

[42]. PradeepKumar AR, Shemesh H, Jothilatha S, Vijayabharathi R, Jayalakshmi S, Kishen A. Diagnosis of Vertical Root Fractures in Restored Endodontically Treated Teeth: A Time-dependent Retrospective Cohort Study. J Endod. 2016 Aug; 42(8): 1175-80. PMID: 27339633

[43]. Praveen K, Narayanan V, Muthusekhar MR, Baig MF. Hypotensive anaesthesia and blood loss in orthognathic surgery: a clinical study. $\mathrm{Br} \mathrm{J}$ Oral Maxillofac Surg. 2001 Apr; 39(2): 138-40. PMID: 11286449

[44]. Priyanka S, Kaarthikeyan G, Nadathur JD, Mohanraj A, Kavarthapu A. Detection of cytomegalovirus, Epstein-Barr virus, and Torque Teno virus in subgingival and atheromatous plaques of cardiac patients with chronic periodontitis. J Indian Soc Periodontol. 2017 Nov-Dec; 21(6): 456-460. PMID: 29551863.

[45]. Putchala MC, Ramani P, Sherlin HJ, Premkumar P, Natesan A. Ascorbic acid and its pro-oxidant activity as a therapy for tumours of oral cavity -- a systematic review. Arch Oral Biol. 2013 Jun; 58(6): 563-74. PMID: 23477602.

[46]. Rajendran R, Kunjusankaran RN, Sandhya R, Anilkumar A, Santhosh R, Patil SR. Comparative evaluation of remineralizing potential of a paste containing bioactive glass and a topical cream containing casein phosphopep- tide-amorphous calcium phosphate: An in vitro study. Pesquisa brasileira em odontopediatria e clinica integrada. 2019; 19.

[47]. Ramamurthy JA, Mg V. Comparison of effect of hiora mouthwash versus chlorhexidine mouthwash in gingivitis patients: a clinical trial. Asian Journal of Pharmaceutical and Clinical Research. 2018; 11(7): 84.

[48]. Ramesh A, Varghese SS, Jayakumar ND, Malaiappan S. Chronic obstructive pulmonary disease and periodontitis-unwinding their linking mechanisms. Journal of Oral Biosciences. 2016 Feb 1; 58(1): 23-6.

[49]. Ramesh A, Varghese SS, Doraiswamy JN, Malaiappan S. Herbs as an antioxidant arsenal for periodontal diseases. J Intercult Ethnopharmacol. 2016 Jan 27; 5(1): 92-6. PMID: 27069730.

[50]. Ramesh A, Vellayappan R, Ravi S, Gurumoorthy K. Esthetic lip repositioning: A cosmetic approach for correction of gummy smile - A case series. J Indian Soc Periodontol. 2019 May-Jun; 23(3): 290-294. PMID: 31143013

[51]. Ramesh A, Ravi S, Kaarthikeyan G. Comprehensive rehabilitation using dental implants in generalized aggressive periodontitis. J Indian Soc Periodontol. 2017 Mar-Apr; 21(2): 160-163. PMID: 29398863.

[52]. Ravi S, Malaiappan S, Varghese S, Jayakumar ND, Prakasam G. Additive Effect of Plasma Rich in Growth Factors With Guided Tissue Regeneration in Treatment of Intrabony Defects in Patients With Chronic Periodontitis: A Split-Mouth Randomized Controlled Clinical Trial. J Periodontol. 2017 Sep; 88(9): 839-845. PMID: 28474968.

[53]. Sajan D, Udaya Lakshmi K, Erdogdu Y, Joe IH. Molecular structure and vibrational spectra of 2,6-bis(benzylidene)cyclohexanone: a density functional theoretical study. Spectrochim Acta A Mol Biomol Spectrosc. 2011 Jan; 78(1): 113-21. PMID: 21050808.

[54]. Svärdström G, Wennström JL. Periodontal treatment decisions for molars: an analysis of influencing factors and long-term outcome. J Periodontol 2000 Apr; 71(4): 579-85. PMID: 10807122.

[55]. Thamaraiselvan M, Elavarasu S, Thangakumaran S, Gadagi JS, Arthie T. Comparative clinical evaluation of coronally advanced flap with or without platelet rich fibrin membrane in the treatment of isolated gingival recession. J Indian Soc Periodontol. 2015 Jan-Feb; 19(1): 66-71. PMID: 25810596.

[56]. Tsai C, Hayes C, Taylor GW. Glycemic control of type 2 diabetes and severe periodontal disease in the US adult population. Community Dent Oral Epidemiol. 2002 Jun; 30(3): 182-92. PMID: 12000341.

[57]. Uthrakumar R, Vesta C, Raj CJ, Krishnan S, Das SJ. Bulk crystal growth and characterization of non-linear optical bisthiourea zinc chloride single crystal by unidirectional growth method. Current Applied Physics. 2010 Mar 1; 10(2): 548-52.

[58]. Varghese SS, Thomas H, Jayakumar ND, Sankari M, Lakshmanan R. Estimation of salivary tumor necrosis factor-alpha in chronic and aggressive periodontitis patients. Contemp Clin Dent. 2015 Sep; 6(Suppl 1): S152-6. PMID: 26604566

[59]. Vijayakumar GN, Devashankar S, Rathnakumari M, Sureshkumar P. Synthesis of electrospun $\mathrm{ZnO} / \mathrm{CuO}$ nanocomposite fibers and their dielectric and non-linear optic studies. Journal of alloys and compounds. 2010 Sep 24; 507(1): 225-9

[60]. Vishnu Prasad S, Kumar M, Ramakrishnan M, Ravikumar D. Report on oral health status and treatment needs of 5-15 years old children with sensory deficits in Chennai, India. Spec Care Dentist. 2018 Jan; 38(1): 58-59. PMID: 29333605.

[61]. Wahab PUA, Madhulaxmi M, Senthilnathan P, Muthusekhar MR, Vohra Y, Abhinav RP. Scalpel Versus Diathermy in Wound Healing After Mucosal Incisions: A Split-Mouth Study. J Oral Maxillofac Surg. 2018 Jun; 76(6): 1160-1164. PMID: 29406253. 